\title{
A REVIEW OF TECHNOLOGY TRANSFER MECHANISMS
}

\author{
L.I. le Grange and A.J. Buys \\ Institute for Technological Innovation \\ University of Pretoria \\ Pretoria, South Africa \\ ianl@hiveld.co.za, ajbuys@up.ac.za
}

\begin{abstract}
This paper gives a review of the theory of technology transfer mechanisms. It is intended as an overview for practitioners. Technology transfer is defined and the technology transfer process discussed. Various technology transfer management tools are presented, such as technology reviews, technology space maps, and technology balance sheets. It concludes with the application of the theory in the form of a new proposed model for technology transfer. The aim of the model is to introduce the basic activities involved in a technology transfer project. The model can be used in a formal technology transfer strategy from the early planning stages, through the measuring of progress and output of the project to the post review of the project.
\end{abstract}

\section{OPSOMMING}

Hierdie artikel gee 'n oorsig van tegnologie-oordrag meganismes. Dit word aangebied as 'n oorsig vir praktisyns. Tegnologie-oordrag word gedefineer en die tegnologie-oordrag proses word in bespreek. Verskeie tegnologie-oordrag bestuursgereedskap, soos tegnologie oorsigte, tegnologie ruimtekaarte en tegnologie balansstate word voorgehou. Ter afsluiting word die toepassing van die teorie in die vorm van 'n nuwe voorgestelde model vir tegnologie-oordrag voorgehou. Die doel van die model is om die basiese aktiwiteite waaruit 'n tegnologie-oordrag projek bestaan duidelik na vore te bring. Die model is geskik vir gebruik as deel van ' $n$ formele tegnologie-oordrag strategie vanaf die vroeë beplanningsfases, deur die meting van vordering en die uitset van die projek, tot die nabetragting na afloop van die projek. 


\section{INTRODUCTION}

The importance of technology and the management thereof is increasingly being recognised as an important strategic consideration by organisations. Technology used by organisations should enable them to be competitive in the global market. Organisations should therefore manage technology and the aspects surrounding technology properly.

One of the important aspects to be considered in the management of technology is the transfer of the most appropriate technology to the organisation. Often technology is developed outside an organisation or as a separate function of the organisation. This necessitates the transfer of the technology from a developer environment to a user environment. Knowledge of the technologies used by an organisation, the technologies available to organisations as well as the technologies used by their competitors, may assist decision-makers in selecting the most appropriate technology.

Technology resides in three key areas, namely those of skill, equipment and knowledge. Technology residing in each of the respective areas may enter an organisation via different mechanisms, some being more effective than others. The findings of this investigation are presented graphically and the main aspects involved in the transfer of technology are summarised in a generic model. The model can serve as a reference in the early planning stages of a technology transfer project and also as a guide against which the progress of the project can be measured. The aspects identified in the generic model provide useful inputs to the strategic decision-making and planning processes.

\section{TECHNOLOGY TRANSFER}

What is 'technology transfer?' Let us start with the concept of 'technology'. For the purpose of the investigation, technology is defined as "specialised knowledge applied to achieve a practical purpose". In other words, scientific knowledge is applied to develop a product or service in order to satisfy an existing or new need. Technology is therefore the culmination of intellectual and physical ingenuity in order to augment human skill, according to Van Wyk[1].

The second concept is 'transfer'. For the purpose of the investigation, transfer not only retains its defined meaning of moving something to another location, but also includes the use of the transferred item. This concept is illustrated by the following example. If a computer program is bought, the intended functionality has not been transferred to the buyer of the programme. Even when the programme is installed, the functionality has not yet been transferred. Only when the buyer uses the programme, certain functionality has been transferred.

Technology transfer therefore means the movement of technology, consisting of knowledge, skills and equipment, from an originator's environment to a user's environment. No transfer has however taken place unless the moved technology is used.

\section{THE TECHNOLOGY TRANSFER PROCESS}

The laws of nature ultimately limit technological improvement in any field. For example, the number of transistors that can be placed on a silicon chip is limited by the crystal structure of 
silicon. According to Van Wyk[1], most industries are however far from these limits and they are much more likely to come up against practical technological limits ${ }^{1}$.

Researchers strive to narrow the gap between the current technology and the limits whether they are, practical or physical. This gap is called the technical potential of technology. Many believe that the technology with the greatest potential takes control of the market, but this is not always the case. There are very often gaps between current and new technology and that is what makes developing new technology so difficult. These gaps may be just big enough for people not to see the benefits of the new technology. This blindness has affected almost every industry. Foster[2] identified the following aspects that may stand in the way of adopting new technologies and discarding the old:

- Incorrect perspective of technical limits

- Inability to measure technological progress

- Faulty interpretations of market signals

- Misinterpreted customer needs

- Culture

- Gap between old and new technology is too big.

\subsection{Recognising a need or opportunity}

The initial step in the transfer of technology process is the recognition of a need. This need must be satisfied by current technology applied differently, or it must be satisfied by new technology. Cooke and Mayes[3] suggests that needs can arise from any the following:

- Scientific changes

- Competition

- The market

- Legislation

- Human inquisitiveness

- Innovation as company policy

Scientific changes can bring about new products utilising new technologies. An example would be the development of nylon, which made it possible to solve needs in a technologically advanced way.

Competition together with the market may be one of the greatest initiators of the need to transfer new technology. The market is becoming increasingly fragmented and more sophisticated. This means that an organisation's products or services must be tailored to address the specific needs of individuals. If an organisation does not have the technological capability to do so, it will loose that market to its competitors. Technology can give a business the competitive advantage it needs to secure its position in the market.

\footnotetext{
${ }^{1}$ Using ceramics inside an internal combustion engine can greatly improve its efficiency but its impact resistance is very low and therefore it restricts the use of ceramics in this application.
} 
Legislation may also create a need that has to be met by obtaining new technology. If we think about the aviation industry in general there are, for example, restrictions on the noise levels of aircraft over populated areas surrounding airports. This legislation disqualifies older aircraft from using these airports. A new need arose and subsequently engine noise was reduced by developing 'hush kits'. At that stage this was a new technology in the aviation industry. Human inquisitiveness together with innovation ensures advances in technology.

\subsection{Searching for technology}

After defining a need an organisation must search for appropriate technology that will best satisfy this need. There are several strategies that can be followed and they can be divided into two major groups. The first is developing the technology yourself and the second is looking for the technology outside the organisation.

Information plays a big role in the search for new, or the most applicable technology. Organisations are particularly interested in information on products, research activities, finance and patent information. One of the successful sources of information and co-operation is higher education institutions in the form of universities. Partnerships with these institutions help companies to:

- Access new technologies

- Keep abreast of new technologies

- Access consultancy skills

- Develop new technologies jointly

\subsection{Identify and Monitoring Information}

Before a technology can be identified that may satisfy a newly identified need, senior personnel (managers and above) must have accurate knowledge of not only the company's technological position but they must also have knowledge about the market and their competitors. This strategy will insure a well-organised approach in obtaining new technology.

Cooke and Mayes[3] identified two prominent roles found in companies concerning the knowledge of technologies. The first is the godfather. This is the person, usually in a senior position in an organisation that watches over the technology transfer process. This person often introduces other senior staff members to the idea of new technology. This is the person that is up to date with the latest developments in his field or market segment, although it is not part of his work description. The role of the godfather may be limited to the development phase of transfer project or even just the role of initiator. The role might however continue throughout the whole transfer project.

The second role found in companies is that of champion. The champion is often found at the middle-management level. The people in this role are often very skilled and will most probably oversee the implementation of new technology, i.e. the programs initiated by the godfather. The role of champion may eventually mature into the role of godfather. The champion has excellent knowledge on internal politics and skills. The person in this role also has great people skills and is a good communicator. 
Out of these two roles we see that the godfather's role has knowledge on the internal state of technology, but even greater knowledge on the external state of technology. If a need arises this is often the person you would go to, to ask, "How are we going to solve this?" A person can fulfil the godfather role in an unofficial capacity, but with organisations, which realise the importance of technology and the acquiring thereof, this is very often an official role. Where the godfather's main role is over-seeing the transfer process from the external environment, the role of the champion is mostly concerned with the internal environment. His role does not include the identification of new technology, but he is an excellent evaluator of chosen technology because of his knowledge of internal affairs. The champion will be able to comment on the appropriateness of the technology. Again, the champion's role can be official or unofficial. The role of the champion can be seen as that of a gatekeeper, who not only has excellent technical knowledge, but also has great people skills and excellent leadership qualities.

For organisations that are concerned with keeping up to date with technology, it is important to identify people that might unknowingly fulfil these roles of champion and godfather and exploit their capabilities. It might even be feasible to give these people official capacity in an organisation to fulfil these roles.

\subsection{Technology Assessment}

When identifying technology it should be assessed in order to find the most suitable technology. Aspects that should be addressed in the assessment process include:

- Strategic implications

- Effect on market and customer

- Operational changes

- Technological abilities of suppliers

- Local suitability of technology

- Personnel

- Training

Before starting the transfer process an assessment criterion should be defined in order to evaluate each identified technology. The team responsible for the transfer of the technology should define aspects to be assessed, and the measurement criteria for each aspect. It is important to involve as many people as possible especially those that will work with, or will be affected by the new technology. By involving all concerned, an objectively defined opinion should be possible and the most appropriate technology can be selected. It must be stressed that the assessment criteria, consisting of objectives and specifications already defined after the identification of the need. This will aid in the transfer process, for each aspect in the transfer process will be measured or assessed according to the defined criteria.

\subsection{Transfer}

Technology transfer takes place via certain mechanisms. Cooke and Mayes[3] indicates that these mechanisms can be identified per area of technology as follow: 
Technology in the form of knowledge can be conveyed through the following mechanisms:

- In print through technical journals

- In print through learned journals

- Scientific magazines

- Patents

- Orally at conferences

- Orally at learned societies

- In discussions with colleagues

- In discussions with acquaintances

- In discussion with consultants

- On television or radio

- Courses

- Service bulletins

- Data packs

- Specifications

Technology in the form of skills is acquired by doing something. It can be conveyed by:

- Watching someone doing something

- Watching a video of someone doing something

- Demonstrations at courses

- Hands-on training

Technology in the form of equipment is conveyed via the following mechanisms:

- Products

- Trade magazines

- Trade conventions

- Sales representatives

- Advertisements

- Direct mail

- Contacts in other companies

Most technology transfer happens between companies. The technology transferred can be in the skills, knowledge or equipment domain. According to Mogavero and Shane[4], all technology transfer models can be divided in two major categories. The first category is passive and the second is active. This classification refers to the level of activity in applying the technology in the transfer process. If the technology transfer mechanism presents the technology to the potential user without assistance regarding its application, then the mode is called passive. In the passive mode only the knowledge part of technology is transferred, the skills surrounding the technology are not transferred. These mechanisms can include presentations in a report. If, on the other hand the provider of the technology assists with the application of the technology then the mode is called active. These mechanisms include training. The boundaries between passive and active are not that easy to define and therefore a semi-active mode is also defined. 


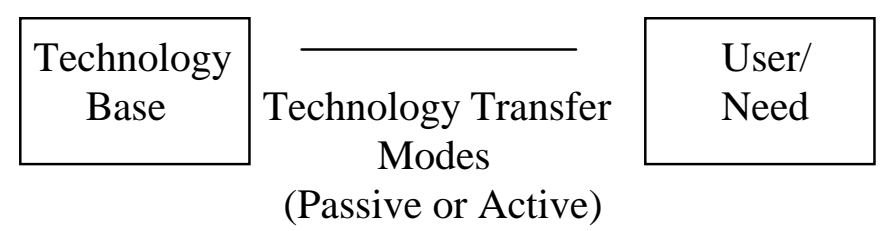

\section{Figure 1: Transfer modes}

(Adapted from Mogavero and Shane[4])

\section{Passive Mode (2)}

The most widely use mechanism in the passive mode is the instruction manual or "cookbook" approach. This is the only contact between the originator of the technology and the user. Millions of products are made and sold with transfer occurring in this form. Just think of the motorcar. These self-teaching manuals used in this mode all have one thing in common: they presume that the user has some level of knowledge and competence in the specific technological area. It is an important point in this mode of transfer. A mechanic can perfectly assemble a component from an instruction manual. This becomes more intricate when we think of other technologies like glassblowing, sheet metal work and woodwork. In these areas the skill that lies with the user, must be far greater. This is important to keep in mind if you want to transfer technology. The skill resting in the user of the technology must be clearly defined by the originator, because this will have a definite impact on the success of the transfer process. If you give someone who does not know how to drive a motorcar that technology, it will be of no value to the person, because it cannot be used.

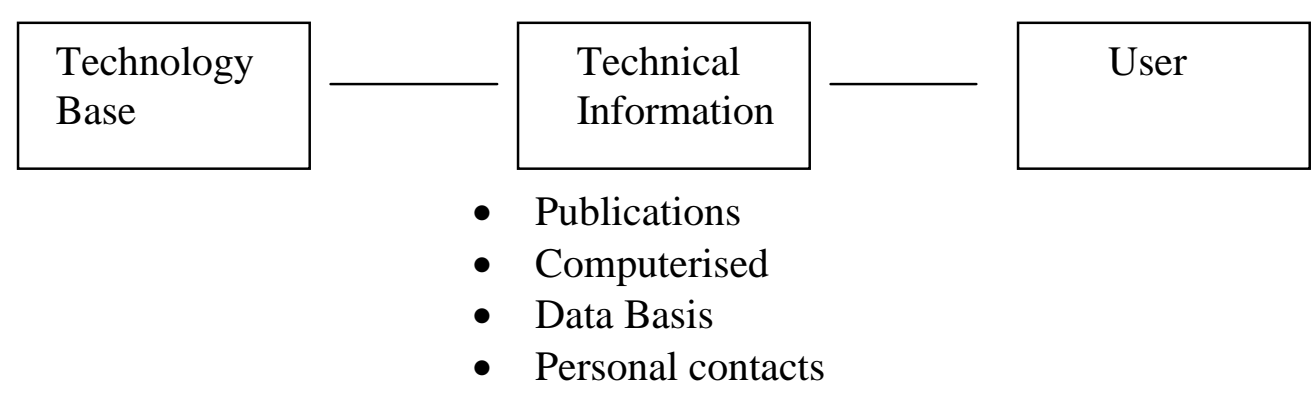

Figure 2: Passive Technology Transfer Mode

(Adapted from Mogavero and Shane[4])

\section{Semi-Active Mode (2)}

In the semi-active mode there is third party intervention in the transfer process. This is usually in the form of a transfer agent. In the semi-active mode the role of the transfer agent is limited to that of adviser. Very often in the semi-active mode, the transfer agent only screens information in the relevant field of interest and passes it on to the final user. He therefore ensures the relevance of the information, about the user's needs, but also because of his knowledge about the technology. The role of the transfer agent is therefore one of communicator between the technology and the user. If his role is beyond this then the mode of transfer becomes active. 


\begin{tabular}{|c|c|c|c|}
\hline $\begin{array}{l}\text { Technology } \\
\text { Base }\end{array}$ & $-\begin{array}{l}\text { Technical } \\
\text { Information }\end{array}$ & \begin{tabular}{|l|} 
Technology \\
Transfer Agent
\end{tabular} & User \\
\hline & $\begin{array}{ll}\text { - } & \text { Publications } \\
\text { - } & \text { Computerised } \\
& \text { Data Basis } \\
\text { - } & \text { Personal } \\
\text { contacts }\end{array}$ & $\begin{array}{l}\text { Secondary advisor } \\
\text { for application of } \\
\text { technology }\end{array}$ & $\begin{array}{l}\text { Primary adopter } \\
\text { of technology }\end{array}$ \\
\hline
\end{tabular}

\section{Figure 3: Semi-Active Technology Transfer Mode}

(Adapted from Mogavero and Shane[4])

The most widely used source of technical information is in the form of written technical documentation and therefore the passive mode of transfer is the most widely used. Because of this care should be taken in the writing of these documents. Very often data banks and published material are searched in order to obtain information on relevant subjects. Experience has shown that what the first would-be user wants to read is a non-technical description of the technology. Because the reader will be trained in one or more technical disciplines, it will be easy for him to judge the relevance of the document. Because of the increasing amount of data this becomes more relevant. This is a time consuming effort and often it is 'outsourced' to a transfer agent. He will then be responsible for identifying relevant information and transferring it to the user. The transfer agent can be in the form of one or several people working in a team, each within their own field of expertise. An additional benefit of using a transfer agent is that the user of the technology may have interpreted the problem incorrectly and this could lead them on the wrong path in the search for a solution. Here the agent can be of help, because of his knowledge of the user's needs.

The passive and semi-active modes are therefore recognised by the fact that no third party participates in the application of the technology. Only limited assistance in identifying relevant technologies is experienced in the semi-active mode.

\section{Active Mode (2)}

\begin{tabular}{|c|c|c|c|}
\hline $\begin{array}{l}\text { Technology } \\
\text { Base }\end{array}$ & \begin{tabular}{|l} 
Technical \\
Information
\end{tabular} & \begin{tabular}{|l|} 
Champion and \\
Team
\end{tabular} & User \\
\hline & $\begin{array}{ll}\text { - } & \text { Publications } \\
\text { - } & \text { Computerised } \\
\text { - } & \text { Data Basis } \\
\text { corsonal } \\
\text { contacts }\end{array}$ & $\begin{array}{l}\text { Secondary advisor } \\
\text { for application of } \\
\text { technology }\end{array}$ & $\begin{array}{l}\text { Primary adopter } \\
\text { of technology }\end{array}$ \\
\hline
\end{tabular}

Figure 4: Active Technology Transfer Mode

(Adapted from Mogavero and Shane[4])

In the active mode not only knowledge is transferred, but also the process is carried through to an actual demonstration of the technology. In this mode of transfer not only words and 
pictures are transferred, but a working system is installed and demonstrated to the users thereof. The transfer process even goes further than this. The user is trained to use the technology. It is clear that the technology transfer agent plays a key role in this transfer mode. The agent does not only identify relevant technologies but also helps in identifying the most appropriate technology. He then also helps with the implementation of the new technology and the training of personnel that will be using the new resources. In order to do this successfully; the agent must have a clear understanding of what the user's needs are. The agent must also have a very good understanding of the technology or must be able to quickly familiarise himself with the technology. The agent must be able to interact with the nontechnical and/or technical user on the one side, and the very technical orientated developers of the technology on the other side. The agent is no longer a feeder of information as in the semi-active or passive modes. The agent has become a technologist, seeking, evaluating and implementing technology in order to satisfy a need or solve a problem.

Organisations who have problems implementing technical solutions themselves, and who are struggling to bridge the gap between technology and the ultimate application thereof benefit most from the active mode of technology transfer is most likely to be found. Organisations like small businesses that do not have their own $R \& D$ departments have to consult a third party on introducing new technology to satisfy their needs.

If they do not consider themselves experts in the field of the new technology and in implementing it, they may also seek the help of an expert in the form of the transfer agent. The transfer agent will also be able to customise the technology in order to be user-friendly in the environment it is to be implemented. The transfer agent is expected to understand each aspect of the technology, while the user is only expected to understand aspects of the technology in order to use it successfully. The success of the active mode of transfer is measured by the degree the ultimate user of the technology is satisfied.

Mogavero and Shane[4] have identified seven minimum aspects that must be present in order to assure the success of the transfer process. These are:

- Firm statement of user needs

- Clearly stated and understood boundary of solutions

- Firm commitment by the user to remain actively associated during and after the transfer

- Participation of representatives of influential interested organisations.

- Market analysis

- The manufacturer

- The champion

The user is responsible, together with the transfer agent to clearly state the need of the user. Both must know exactly what the problem is, or a solution will not be found, or you find a solution, but to the wrong problem. The number of solutions to a problem may vary dramatically and therefore a boundary must be defined within which the ultimate solution must fall. The constraint on the solutions may be of cost, weight, size, etc. The responsibility of defining the solution boundary lies with the user. This should be done as early as possible in the transfer process. 
As the transfer process evolves, there is a probability that the selected technical approach may lead to a dead end or it may require a new concept. It may even lead to a whole new solution. A firm commitment is therefore needed by the user to remain actively involved in the transfer process. There must be certain flexibility in the thinking of not only the user, but also the transfer agent. Pursuing one solution may bring forth-another solution and both parties must be aware of this. Both parties cannot allow a setback to deter them from finding a suitable solution.

The user must also ensure beforehand, that the search and implementation of the new technology is well accepted by organisations within the user's environment. These include labour unions, management associations', etc. The more actively these organisations can be involved in the transfer process, the greater the probability of success. The user must show how the implementation of the new technology will benefit all concerned. If this is not done, a group can derail a transfer project that would have brought major benefits to the user.

One of the factors that may have the most negative impact on a transfer process may be something that lies outside the process. This factor is market acceptance of the new technology. Every aspect of the transfer process may be executed to perfection to bring forth a solution, but if the market does not accept the solution, all the effort is in vein. This is the reason why a good market analysis should form part of any good transfer process. The effect of the technology on the market place can therefore not be ignored. Another big role player in the transfer process is the manufacturer or developer of the product or solution. It is important to identify and consult him/her as early as possible in the transfer process, for they play an important role in the development of the ultimate solution. The last of the seven aspects is the champion. This is the motivator for the whole project from the user's side. This is the person that gives direction to the project and keeps people motivated to see the project through.

\subsection{Barriers to transfer}

According to Cooke and Mayes[3], the following can be seen as barriers to technology transfer or factors that may have a negative impact on the transfer of technology:

- Management attitudes

- Resistance to change

- Poor information flows

- Poor communication

- Lack of time

- Too expensive

- Current product/procedures meet the needs

- Too much red tape

- Knowledge and skills adequate

Some of these aspects may have a greater influence on transfer of technology from outside an organisation than on the transfer process inside an organisation. Management attitudes can greatly impact on the transfer of appropriate technology from outside the organisation because 
they are in a decision making position on the part of the organisation. The impact is less from an internal point of view.

Resistance to change has a greater effect inside the organisation than from the outside. If top management does not steer the company in the correct direction, the organisation may cease to exist and the reluctance to change may mean the end of the organisation. When one looks at the situation inside the company there is always a reluctance to change. Unwillingness to change inside a company does not necessarily mean that the organisation will not succeed. It is difficult to change the mindset of people if procedures haven't changed for the past 10 to 15 years. 'I have been doing this for 10 years, why must a change now' is an often heard comment in the workplace. Therefore the reluctance to change increases as one moves down the hierarchy of the company, because change may secure the future of the company and not all levels in the company may see it that way.

Poor information flow and poor communication may be one of the greatest barriers to transfer experienced in the South African Aviation industry. Poor communication inside an organisation may be the killer of innovative ideas on aspects like productivity. Very often the people working with a certain technology are not consulted when management starts looking for more effective ways applying technology. It is also of great importance that management knows the state of the industry their organisations operate in. Internal communication channels must be developed inside their industries in order to stay familiar with the latest advances in technology in their industry. By doing this they can identify gaps between the technology they use and the technology available in the industry and try to narrow these gaps. In the current competitive environment organisations cannot compete with old technology.

As we saw, the transfer process takes time and many managers see this as lost time. They must however keep in mind the benefits of the new technology compared to the old technology. If a proper transfer model is in place, the effort and the time may be reduced substantially, especially if there are dedicated people that are responsible for technology transfer projects. The issue of cost may also be a barrier. Again proper care must be taken in weighing and the pros and cons of new technology that must replace older technology.

If the current knowledge base or products/procedures meet the current needs, there is no reason for the transfer of new technology. This cannot really be seen as a barrier especially when looking at the short term. It can, however, become a barrier when looking further into the future, especially when current technologies are still fulfilling their function. The reasons for looking at new technologies are not easily justified in this situation.

Too much red tape may also be a barrier to the transfer process. Red tape may be a combination of one or more of the other barriers mentioned. The attitude of people towards the transfer of technology may also play a big role as a barrier to transfer.

\subsection{Internal technology review (audits)}

Internal technology reviews are a very important exercise for any organisation in order to define their technological position. A review of this kind usually covers three important aspects. These aspects are: 
- Review of the company's technological position

- Review of competitor's technological position

- Review of supplier's technological abilities

- Review of client's capabilities

- Review of local suitability of technology

- Review of state-of-the-art technology

These three aspects translates into 'what they've got, what we have, and what we could have.' A review of this nature has a few benefits apart from defining an organisation's technological position. It helps to create an awareness of people concerning technology. It also keeps people informed and this may translate into better decision-making. The difference in technology used by an organisation and its competitors may translate into competitive advantage or disadvantage, as seen by the organisation. A review of this nature can therefore have a great impact on the realisation of competitive advantage and an organisation can see, as a result of the review, where they are, or why their competitors have the competitive advantage. Another outcome of the technology audit is the technology portfolio of a company. The portfolio is a list of technologies used by an organisation. A review also defines an 'external' portfolio. This is a portfolio of technologies that is available to the organisation.

The review should include the technological abilities of your suppliers and an ongoing awareness of the evolution thereof. Once you utilise a source of technology, you have to monitor it as if it were inside your own company, especially if you buy products containing the key technology. You need to also review your client's capabilities. Their conservatism could trap you in an old technology or their enthusiasm entice you into a new technology too soon. Their relevant capabilities should be made visible in your technology audit.

The need often arises to adapt a technology to its destination context - typical factors in this case are things like electricity supply, water and air quality, environmental regulations, employee skill profiles and culture, local availability and cost structures for materials and components and so on. The assessment should therefore include the local suitability of technology.

Great care has to be taken when launching a review of this kind. The biggest problem is always to obtain an objective view. For this reason special care must be taken in selecting the individuals that will participate in the audit. It should be people across the organisation and from all hierarchies, which are directly involved or affected by technology and the change in it. A proper workshop should explain the goals of the exercise, and all participants should have a clear understanding of the process. Internal as well as external views can be obtained from suppliers and/or customers. The difficult part is obtaining information concerning technologies used by the competition.

\section{Technology Space Maps}

It is important to know what technologies are available to the company and what technologies the immediate competition employ. De Wet[5] suggests a technology space map (TSM) as a tool that can be used in auditing a company's technological position. A technology space-map is a practical tool for assessing technological capabilities. It is therefore an ideal tool to use in 
a technology audit. By looking at this map the experienced technologist can determine the scope and content of technology and this acts as a launch pad to initiate appropriate transfer projects.

Figure 5 indicates a typical space-map with the one dimension being the system life cycle and the other, the system hierarchy. These maps are very flexible and any two dimensions can be specified in order to customise the map for individual companies.

The TSM can be expanded to include a third dimension as shown in Figure 6. The third dimension defines the technology or technologies used in each of the areas specified on the TSM. For instance the identified area in the matrix Product-Maintain will have certain technologies associated with it and so for each area in the matrix the technologies can be listed. If a company wants to extend their business into new areas, it is indicated on the TSM and the additional technologies needed to expand their business can then be listed.

\begin{tabular}{|l|l|l|l|l|l|l|}
\cline { 2 - 6 } \multicolumn{1}{c|}{} & \multicolumn{5}{c|}{ System Life-Cycle } \\
\hline System hierarchy & Research & Design & Develop & Produce & Maintain & Distribute \\
\hline User System & & & & & \\
\hline Product System & & & & & & \\
\hline Product & & & & & & \\
\hline Sub System & & & & & & \\
\hline Component & & & & & & \\
\hline Material & & & & & & \\
\hline
\end{tabular}



Figure 5: Technology Space Map - Two-dimensional (Adapted from De Wet[5])

\section{Technology Balance Sheets}

Another very useful tool also suggested by De Wet[5], is the technology balance sheet. The technology balance sheet provides a snap shot of where a company stands currently, and where it would like to go concerning technology. One of the main functions of a TBS is providing a list of technologies relevant to the current business. The TBS also gives an indication of which technologies available to the company may be relevant to the company when expanding into new products or markets. In Figure 7 we can see that the products with their relevant markets, processes and technologies are indicated.

The TBS also indicates the ease with which new technologies can be identified when expanding into any of the dimensions in the TBS. It can also help with identifying new products and markets when a new technology can be obtained or developed in-house. 
Any company involved in a technology audit should consider the use of these two excellent graphical tools in order to define their technological position. A good intelligence strategy can help you to learn from the best practice of competitors. It also assures that an organisation obtains new technologies that are available and also ensures good internal communication.

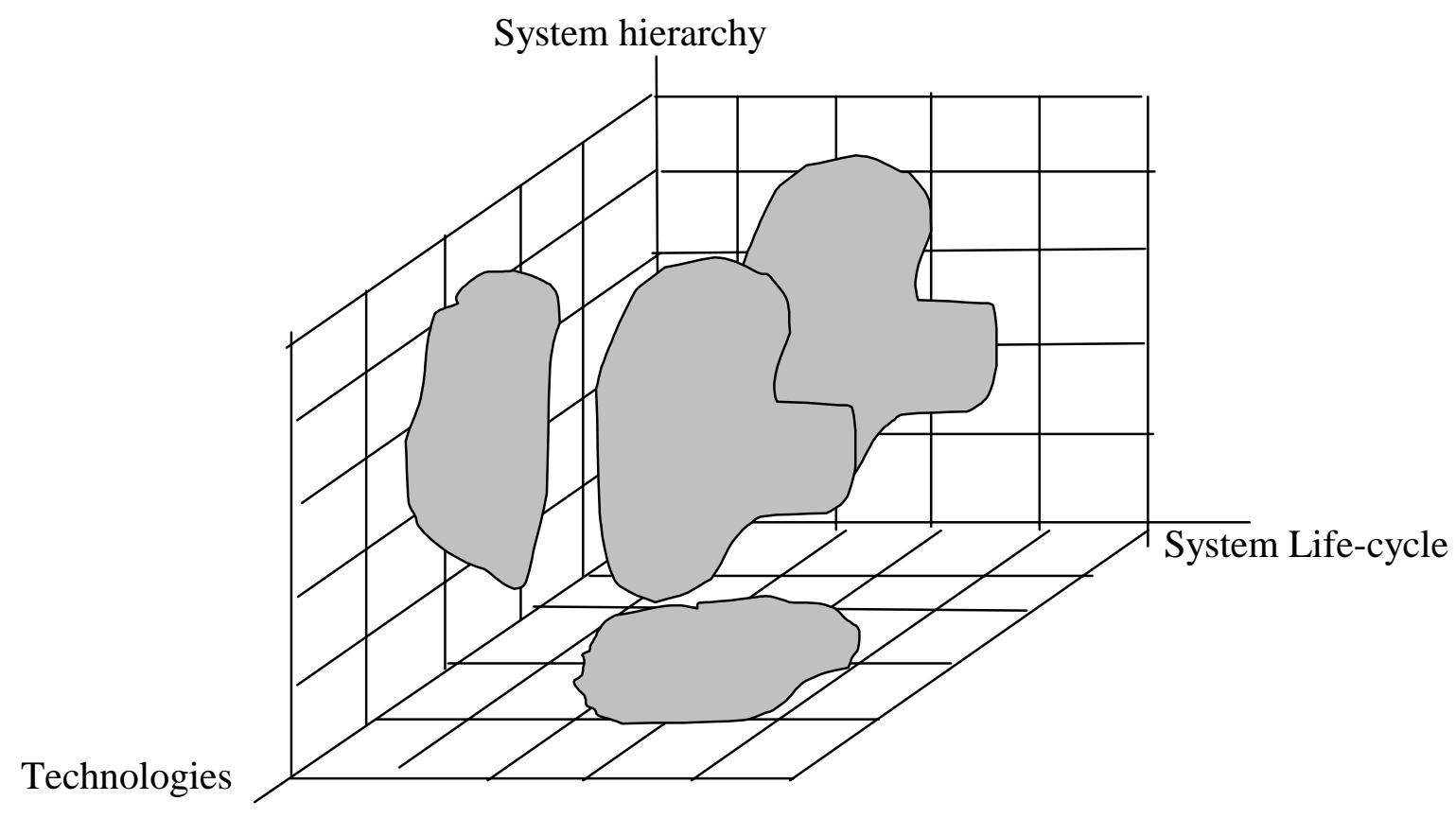

Figure 6: Technology Space Map - Three-dimensional

\begin{tabular}{|c|c|c|c|c|c|c|c|}
\hline & & Product 1 & Product 2 & Product 3 & Product 4 \\
\hline & & & Market 1 & $\mathrm{x}$ & & $\mathrm{x}$ & $\mathrm{x}$ \\
\hline & & & Market 2 & $\mathrm{x}$ & $X$ & $\mathrm{x}$ & $\mathrm{X}$ \\
\hline & & & Market 3 & $\mathrm{x}$ & & $\mathrm{x}$ & \\
\hline \multicolumn{8}{|c|}{ Technologies } \\
\hline \multirow[t]{3}{*}{ T0 } & $\mathrm{T} 1$ & $\mathrm{~T} 2$ & Processes & & & & \\
\hline & $\mathrm{X}$ & $\mathrm{x}$ & Process 1 & $\mathrm{x}$ & $\mathrm{X}$ & $\mathrm{x}$ & $\mathrm{x}$ \\
\hline & $\mathrm{x}$ & $\mathrm{x}$ & Process 2 & $\mathrm{x}$ & & $\mathrm{x}$ & $\mathrm{x}$ \\
\hline $\mathrm{X}$ & & $\mathrm{X}$ & Process 3 & & $\mathrm{X}$ & & $\mathrm{x}$ \\
\hline
\end{tabular}

- New product introduction

Figure 7: Technology Balance Sheet

(Adapted from De Wet[5])

\subsection{Value of technology transfer to the company}

The benefits of transferring appropriate technology has been categorised by Cooke and Mayes[3] as follow: 
- Increased competitive advantage

- Improvement in quality

- Cost savings

- Flexibility

- Reduction in lead times

- Better service to customer

Identifying, transferring and implementing appropriate technology can be beneficial to a company in the above-mentioned areas.

\section{Newly Proposed Model}

The aim of the proposed model is to introduce the basic activities involved in a technology transfer project. The model can be used in a formal technology transfer strategy from the early planning stages, through the measuring of progress and output of the project to the post review of the project.

The following model is proposed for describing the process from need identification to using the technology. For the purpose of the model the following steps are identified:

- Identifying the need

- Searching/Developing the technology

- Evaluating the technology

- Transferring the technology

- Customising technology

- Implementing technology

- Managing technology

These steps are indicated by the following flow diagram:

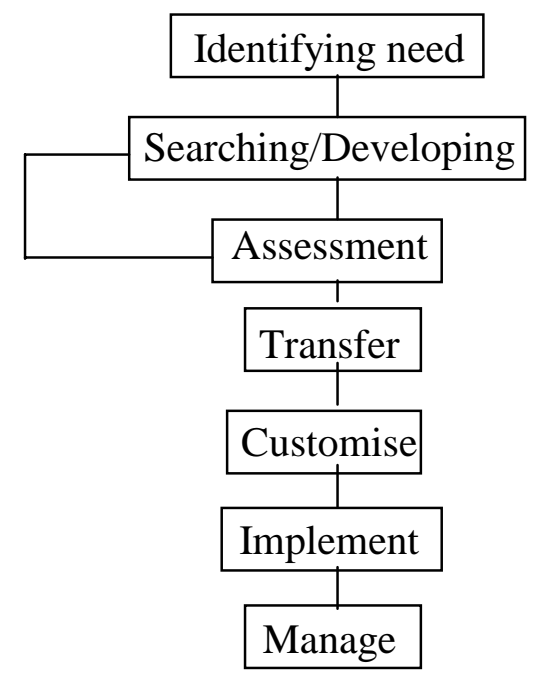

Figure 8: Transfer process 
The first step of the transfer process is the identification of the need. With the identification of the need, one actually defines the desired output of the system. The system in this case will represent a technology or technologies that will satisfy the need. The main aim of the system will be to reach this goal, defined by the desired output as fast as possible. The red line indicates what you want to do, what need you want to address. In this step it is important to clearly define the objectives and specifications, because the whole effort will be measured against it.

The first effort in the process of identifying the need is searching and identifying the potential appropriate technologies that will satisfy the need effectively. These technologies may be found internally or outside the company. Any of the sources mentioned earlier in this paper could be used in order to find the most appropriate technology. The company may also opt to develop the technology themselves if they have access to the relevant resources like an R\&D laboratory.

The third step is evaluating candidate technologies. The candidate technologies should be evaluated according to the clearly defined objectives and specifications defined in the first step. It is now clear why this was such an important step, namely defining the objectives and specifications of the system. As illustrated in the flow diagram, this step has a feedback to the search/develop step. This is due to the fact that this is an evaluation step and the technology may not be suited for the application. Therefore one must go back and search further for more applicable technology. It is important to note that if you have to go and search for technology in order to satisfy a need, the need is probably unique and there will not be a technology developed specifically with your application of it, in mind. In short you will look for a technology with the best fit, one that would satisfy most of your needs, and one that is flexible enough in order to be customised to specific needs. The evaluators of the technology must keep in mind that the technology itself is dynamic and there might be future developments in the technology. There is thus a potential for improvements in the technology. This may have an effect on the application of the technology.

The line that indicates the technology level that would satisfy the need may even be a sloping line with a positive gradient, due to the fast development in the technology. The personal computer (PC) industry is a good example. If you want to develop a programme for a PC application, do you develop it for the current state in PC performance, or develop it for the performance in a year's time. The most important point is selecting a technology in which the potential development will benefit the application of the technology.

The forth step is getting the technology into the company i.e. transferring it. This can be done via several mechanisms already discussed. The transfer can be in the passive or active mode, the active mode being the mode where a third party is involved in helping with the transfer process between the developer and the user. In this step not only do the physical (hardware) components of the technology enter the user domain, but the training of the resources also commences.

In the fifth step the technology is customised to the users specifications and liking. The technology is tweaked in order to satisfy the specific needs of the user, defined in the first step of the transfer process. 
During the sixth step the final implementation is completed. In this step all the resources that will be using the technology are introduced at their respective levels. This is also the step where the new technology is being used for its intended purpose. If the technology replaces older technology, it often runs parallel to the older technology, while the operations of last named is scaled down. The training is completed during this step and any initial problems are solved.

The seventh and final step lasts for the rest of the life of the technology. In this step the technology is managed over the rest of its life. Not only is the technology managed but also the resources using it. Several aspects that are looked at from a management perspective include:

- Incorporating improvements in the technology

- Monitoring competing technologies

- Monitoring the fitness of the technology

Management of the new technology should include the monitoring of improvements in the technology and the incorporation of any improvements, if it is beneficial and relevant to the application. Any improvements identified by the users of the technology should also be considered. These improvements are more likely to be incremental where as during the implementation phase the changes are likely to be more drastic.

The second point is the monitoring of competing technologies. Because technology can give a company the competitive edge, competing technologies may pose a threat. Such technologies should then be considered to succeed current technology. The last point is the fitness of current technology. The question should be asked whether the current technology is still able to deliver what is expected of it.

The final managerial task after implementing new technology is to assess the success of the transfer process. In order to do this the project should be evaluated according to the objectives and specifications defined in the first step of the model.

It is clear that in this final step, which lasts for the rest of the life of the technology, different management principles are used as opposed to the first five steps in the process. In the final step, general management principles are used to manage the technology from day to day. In this phase the technology is used, while in the previous steps the technology was being implemented.

This model serves as a starting point to the introduction of a formal technology transfer project. The model can easily be customised according to each project's needs. It also serves as a handy management tool to people involved in technology transfer projects. It is important to note the difference in the managerial aspects during first six steps and the last step. In the first six steps project management principles are used while in the final step general management principles are applied. 


\section{CONCLUSION}

This paper reviewed of the theory of technology transfer mechanisms. Various technology transfer management tools were presented, such as technology reviews, technology space maps, and technology balance sheets. It concludes with the application of the theory in the form of a new proposed model for technology transfer.

The model presented may be used as a starting point for organisations that want to manage a very important 'resource' in the form of technology and then specifically the transfer of technology. Various parts of the model can however be researched in greater detail. Further research into this the model may bring forth answers to common problems in a transfer project. The problems encountered may be present in a specific stage of the project and some problems may even be industry specific. Another aspect that may be investigated is at what point in time the complete transfer of technology has taken place. Research of this nature will answer questions like when is a technology established in an organisation.

This study succeeded in its aim to provide a model, which summarise the most important aspects involved in a technology transfer program. The model can be used in a formal technology transfer strategy from the early planning stages, through the measuring of progress and output of the project to the post review of the project.

\section{REFERENCES}

[1] Van Wyk, R.J., 1988. "Management of technology: new frameworks", Technovation, Vol. 7, pages $341-351$.

[2] Foster, N.F., 1986. "Timing technological transitions", Technology in the Modern Corporation: A Strategic Perspective, Pergamon Press, Inc.

[3] Cooke, I. and Mayes, P., 1996. "Introduction to Innovation and Technology Transfer", Artech House Inc, London.

[4] Mogavero, L.N. and Shane, R.S., 1982. "What Every Engineer Should Know About Technology Transfer and Innovation", Marcel Dekker Inc.

[5] De Wet, G., 1997. "Technology Space Maps for technology management and audits", Faculty of Engineering, University of Pretoria.

\section{BIBLIOGRAPHY}

[1] The following list of suggested reading material is offered to readers that would like to read more about this subject:

[2] Albino, V., Garavelli, A.C. and Schiuma, G., 1999. "Knowledge transfer and inter-firm relationships in industry districts: the role of the leader firm", Technovation, Vol. 19, pages $53-63$.

[3] Austin, W., et. al., 1997. "Coordinating the Technology Transfer and Transition of Information Technology: A Phenomenological Perspective", IEEE Transactions on Engineering Management, Vol. 44, No. 4.

[4] Barton, L. and Cartwright, G.P., 1997. "Reciprocal Technology Transfer - Changing Partnerships", Change, March/April 1997. 
[5] Chakrabarti, A.K. and Dror I., 1994. "Technology transfers and knowledge interactions among defense firms in the USA: an analysis of patent citations", International Journal on Technology Management, Vol. 9, No. 5/6/7.

[6] Coleman, F., et. al., 199?. "Who, What, Why, and How of Technology Transfer", Transportation Research Record 1637.

[7] Cooke, I. and Mayes, P., 1996. "Introduction to Innovation and Technology Transfer", Artech House Inc, London.

[8] Correa, C.M., 1994. "Trends in technology transfer: implications for developing countries", Science and Public Policy, Vol. 21, No. 6, pages 369-380.

[9] De Wet, G., 1992. "Corporate Strategy And Technology Management: Creating the Interface", Ver. 2, CSIR, Pretoria.

[10] Gilbert, M. and Cordey-Hayes, M., 1996. "Understanding the process of knowledge transfer to achieve technological innovation", Technovation, Vol. 16, No. 6, pages 301-312.

[11] Guillermo Perez-Bustamante, 1999. "Knowledge management in agile innovative organizations", Journal of Knowledge Management, Vol. 3, No. 1, pages 6-17.

[12] Inkpen, A.C. and Dinur, A., 1998. "Knowledge Management Process and International Joint Ventures", Organization Science, Vol. 9, no. 4, pages $454-468$.

[13] Isaacs, E.A. and Tang, J.C., 1996. "Technology Transfer: So much research, so few good results.", Communications of the ACM, Vol. 39, No. 9, pages $23-25$.

[14] O’Dell, C. and Jackson Grayson Jr., C., 1999. "Knowledge Transfer: Discover your value position", Strategy and Leadership, vol. 27, pages $10-15$.

[15] Rogers, E.M., Carayannis, E.G., Kurihara, K. and Allbritton, M.M., 1998. "Cooperative research and development agreements (CRADAs) as technology transfer mechanisms", R\&D Management, vol. 28, no. 2, pages $79-88$.

[16] Roth, D.H., Hendriks, J.L., Whalen, M.F., Bodis, J.R. and Martin K., 1996. "Commercial implementation of NASA-Developed Ultrasonic Imaging Methods via Technology Transfer", Materials Evolution, November 1996, pages 1305 - 1309.

[17] Snyder, S.B., 1996. "Technology Transfer Through Cautious Eyes", Journal of Communication, Vol. 46, No. 3, pages 183 - 192.

[18] Stadler, C., 1999. "The peripheral vision of knowledge managers", Knowledge Management, Vol. 1, No. 1, pages 16-21.

[19] Verksalo, M. and Lappalainen, P., 1998. "A method of measuring the Efficiency of the knowledge Utilization process", IEEE Transactions on Engineering Management, Vol. 45, No. 4.

[20] West, A., 1992. "Innovation Strategy", Prentice-Hall. 